\title{
A REVIEW OF THE BALSAM WOOLLY APHID IN NEWFOUNDLAND ${ }^{1}$
}

\author{
By W. J. CARROLL and D. G. BRYANT ${ }^{2}$
}

W. J. Carroll was born in Bonavista, Nfd., in 1922. He attended Memorial University College, St. John's, Nfld., and Dalhousie University, Halifax, N.S., graduating with a B.Sc. degree in 1948. He received an M.Sc. degree from McGill University in 1952 and is now a candidate for a Ph.D. degree at the N.Y. State College of Forestry at Syracuse. He joined the staff of the Forest Biology Division in 1949 and has been Officer-in-Charge of Forest Biology investigations in Newfoundland since 1950.

D. G. Bryant was born in Montreal, P.Q., in 1931 and lived in and near that city for most of his life. He received his B.Sc. in Forestry from the University of New Brunswick in 1958 and has been accepted for postgraduate studies towards an M.Sc. in Entomology at McGill University in 1960. He joined the staff of the Forest Biology Laboratory, Corner Brook, Newfoundland, in 1958.

\section{ABSTRACT}

The balsam woolly aphid, Adelges piceae (Ratz.), first recorded in Newfoundland in 1949, is now the most serious forest insect pest in the Province, having spread over an area of more than 1,600 square miles. Its host is balsam fir, Abies balsamea (L.) Mill. There are three separate infestations, the largest and most important being in southwestern Newfoundland. The aphid has two generations a year. A biological control program was initiated in 1952 and seven species of predators have been released, three of which are established. Silvicultural and climatic control factors are discussed and the possibilities for the extension of outbreaks are considered.

\section{INTRODUCTION}

The balsam woolly aphid, is an important pest of balsam fir, in parts of Newfoundland and has caused considerable damage, particularly in the southwestern corner of the Island. The aphid was first recorded in North America in 1908 at Brunswick, Maine, (7). In 1929, Swaine reported it in Nova Scotia (11), and subsequent studies by Balch (1) established that it was of European origin, probably introduced before 1900 . In 1949, two separate infestations were discovered in Newfoundland, a severe one in the Codroy Valley near Port aux Basques and a lighter one on the Avalon Peninsula near St. John's (10). A third independent outbreak was reported from the Burin Peninsula in 1955 (9). Since 1951 annual surveys to determine the distribution of the insect, together with studies on its seasonal history and the establishment of introduced predators, have been conducted. This review will include some of the results of these studies with special emphasis on the history of the insect in Newfoundland, and its control and future status. An extensive treatise by Balch (1) includes a detailed discussion of the biology and ecology of the aphid in the

\footnotetext{
${ }^{1}$ Contribution No. 647 Forest Biology Division, Research Branch, Department of Agriculture, Ortawa, Canada. Cost of publication shared by the Forest Biology Division and the C.I.P. 'Forest Biology I.aboratory, Corner Brook, Newfoundland.
} 
Maritime Provinces. Much of the information presented, particularly the descriptions of seasonal history, feeding habits, and nature of injury, is applicable to Newfoundland and will be included here in a condensed form.

\section{Host aNd Nature OF INJURY}

The balsam woolly aphid attacks balsam fir in Newfoundland. This species comprises more than 75 per cent of the softwood stands of western Newfoundland and about 60 per cent of those of central and eastern Newfoundland, and is the principal species upon which the pulp and paper industry depends. In areas where severe infestations have developed it is gradually being reduced to the status of a weed tree, a situation which would have serious economic effects should the insect continue its spread. In spite of persistent attacks by the aphid, fir continues to be highly prolific and will probably remain as the predominant species.

Two terms, twig attack and stem attack, are used in describing infestations. The separation suggested by this terminology is somewhat artificial and erroneous. Twig attack is actually not a form of attack but a description of a symptom caused by the feeding of moderate to high numbers of aphids on the branches over a period of a few years. Aphid feeding causes a swelling of the shoots and twigs and an inhibition of the buds, and ultimately a dying back of the topmost branches. This condition is called gout and has been the common form of injury in Newfoundland. Gout usually develops rapidly during the early years of attack, but later, reduced numbers of aphids cause a slow deterioration of the tree, often lasting 10 to 20 years. Stem attack refers to moderate to high numbers of aphids concentrated on the stem. A salivary substance reacts on the cambium resulting in the formation of enlarged annual rings of brittle reddish-brown wood; later the rings are smaller, apparently due to reduced tree vigor. Severe stem attack may cause death of the tree within two to five years. Lumber from such trees warps and checks because of uneven shrinkage of the wood. An experiment to assess the pulp qualities of the affected wood conducted by Bowater's Newfoundland Pulp and Paper Mills, Ltd. (4), showed that fibres were short and brittle and the burst and tear factors of the paper were low, resulting in an inferior product.

\section{Seasonal Development}

The aphid has two generations each year. The spring (hiemosistens) generation develops from first stage larvae (neosistentes) that have been in overwintering diapause. Commencement of feeding has been observed as early as April 24, but does not normally begin until the first week in May. Development is fairly rapid after this and the first adults appear about the end of May. In the first week of June about 30 per cent of the aphids consist of ovipositing adults and at mid-June 60 per cent have commenced oviposition. The first generation is completed between the last week of July and the first week of August. Differences in the time and rate of development have been noted between localities, between trees, and between individuals on the same tree. These differences apparently result from variations in the regional climate and the microclimate of the bark or twigs, and from individual differences between the insects, although influenced in some cases by the quality of the tree, as development is generally faster on young vigorous trees. 
The progeny of the hiemosistentes comprise the second (aestivosistens) generation. The newly-hatched larvae, or crawlers, are capable of rapid movement for a period of a few hours to several days before settling and inserting their stylets. They have been observed from June 12 to August 1. The newly settled larvae enter a mid-summer diapause of from one to several weeks, but all larvae have completed diapause by the last week of August. The first adults of the second generation appear in mid-August and commence oviposition. Eggs begin hatching in early September and after a short motile period the larvae enter an overwintering diapause. It is during the motile periods that dispersal occurs by wind blowing the free crawling larvae. Observations at the end of the season have indicated that about 60 per cent of the larvae settle on trees and enter diapause, and the remainder, consisting of crawlers and unhatched eggs, are killed by frost.

\section{ORIGIN OF INFESTATIONS}

The balsam woolly aphid was undoubtedly in southwestern Newfoundland a number of years prior to its discovery in 1949. An unpublished report to the Newfoundland Forest Protection Association, 1945, referred to the damaged trees in the Codroy Valley but attributed the cause to blight or exposure (8). Some of the older residents recall that the deterioration of balsam fir was apparent 20 years ago. In an attempt to determine the approximate time of initial infestation at St. Fintans and Robinsons, measurements were made of the annual linear growth of stems of infested and uninfested 45- to 50-year-old balsam fir trees for 20 years prior to 1953. Ten infested trees were selected at each location and 10 uninfested check trees at St. Fintans. Linear growth was approximately the same for the two groups of trees prior to 1941 after which the infested trees showed a marked decline, while the uninfested trees continued at about the same level as before. The reduced growth was more pronounced at St. Fintans, possibly because the infestation was established earlier. Although these data are not adequate for a definite conclusion, they support other evidence that the aphid was well established at St. Fintans about 1940 and was probably introduced to the southwest corner of the Island about 1930 .

It is difficult to say how the insect was introduced. The most logical suggestion is that motile larvae were transported on air currents from Nova Scotia. Another possibility is that either eggs or crawlers were brought from the mainland on dunnage, or even on living trees, not necessarily balsam fir, imported for ornamental purposes. Certain exotic species of trees have been observed in the Codroy Valley although their origin is unknown.

The presence of the aphid in eastern Newfoundland can probably be attributed to an accidental introduction on nursery stock from Europe, probably silver fir, A. alba Mill., its European host. It is interesting to note that this ornamental species shows no symptoms of injury by the aphid. Although the exact date of importation of silver fir is uncertain, it is known that coniferous trees were brought to Bowring Park from Europe prior to 1915 and deciduous trees until 1939. The aphid was probably introduced with its host, which would indicate that the attack began before 1915 . If this is correct, it is surprising that damage has not been more severe. Possibly the intensive cutting of balsam fir in this area and the policy of removing visibly affected trees in and around Bowring Park helped to reduce the number and intensity of outbreaks. 
The Burin Peninsula infestation may have originated from infested wood products and dunnage transported on trading vessels from Nova Scotia and western Newfoundland. Another possibility is that it may have been carried on air currents from the mainland. Estimates based on linear growth measurements similar to those carried out in southwestern Newfoundland indicate that this outbreak began at least 8 to 10 years preceding discovery in 1955 .

Development of Infestations Since 1949

The boundaries of the infestations have been determined annually since 1949 by Forest Insect Survey personnel using aerial and ground surveys of symptoms of attack. As it may take from one to three years for symptoms to develop, the records are not a precise indication of rate of spread, or occurrence of the insect in a given area.

In 1949, the outbreak in southwestern Newfoundland extended over an area of about 300 square miles (Fig. 1). In 1951, the northern boundary was near Stephenville and the eastern boundary was about 20 miles from the coast. In 1954, the infestation had extended an additional eight miles and four isolated spots of predominantly stem attack were discovered near Corner Brook. These locations were about 40 miles north of the main infested area. Small patches of stem attack were recorded in 1955 fifteen miles east of Corner Brook, and in 1956 at Trout River, about 90 miles north of the main infestation. There was also an extension of the outbreak in an easterly direction in the Stephenville area along the river valleys for about 25 miles from the coast. The infested area in 1956 was about 1,000 square miles.

Spot infestations were discovered in several new outlying areas in 1958. Except for the development of a generalized twig attack spreading from spot infestations, no noteworthy extension of the outbreak occurred in 1959. The infested area is about 1,600 square miles, having extended 100 miles since 1949 , indicating a spread of about 10 miles per year. The most severe injury and the most rapid development of outbreaks have been in coastal regions and river valleys, influenced possibly by topography in relation to prevailing winds and by the more favourable coastal climate.

The infestation in eastern Newfoundland was noted in 1949 at Bowring Park, St. John's West, and in adjoining stands of balsam fir. More detailed investigations in 1954 determined the outbreak to cover about 50 square miles, extending about 25 miles west of St. John's (Figure 1). The most severe injury was centred in and around the Park. Most of the infested trees in the area have been removed and the outbreak is now less evident than in 1949. There has been no apparent increase in its size since 1954.

The Burin Peninsula infestation when investigated in 1956 included about 80 square miles across the southern end of the Peninsula. The most severe injury occurred near the centre of the outbreak. No increase in area was evident in 1959 although there was a noticeable increase in the number of aphids and damage to balsam fir.

\section{EFfects on THE STAND}

Permanent sample plots were established by the Forest Insect Survey in 1951 to record the progress of infestations in balsam fir stands. The trees are retallied each year and classified according to infestation and condition. Tables 


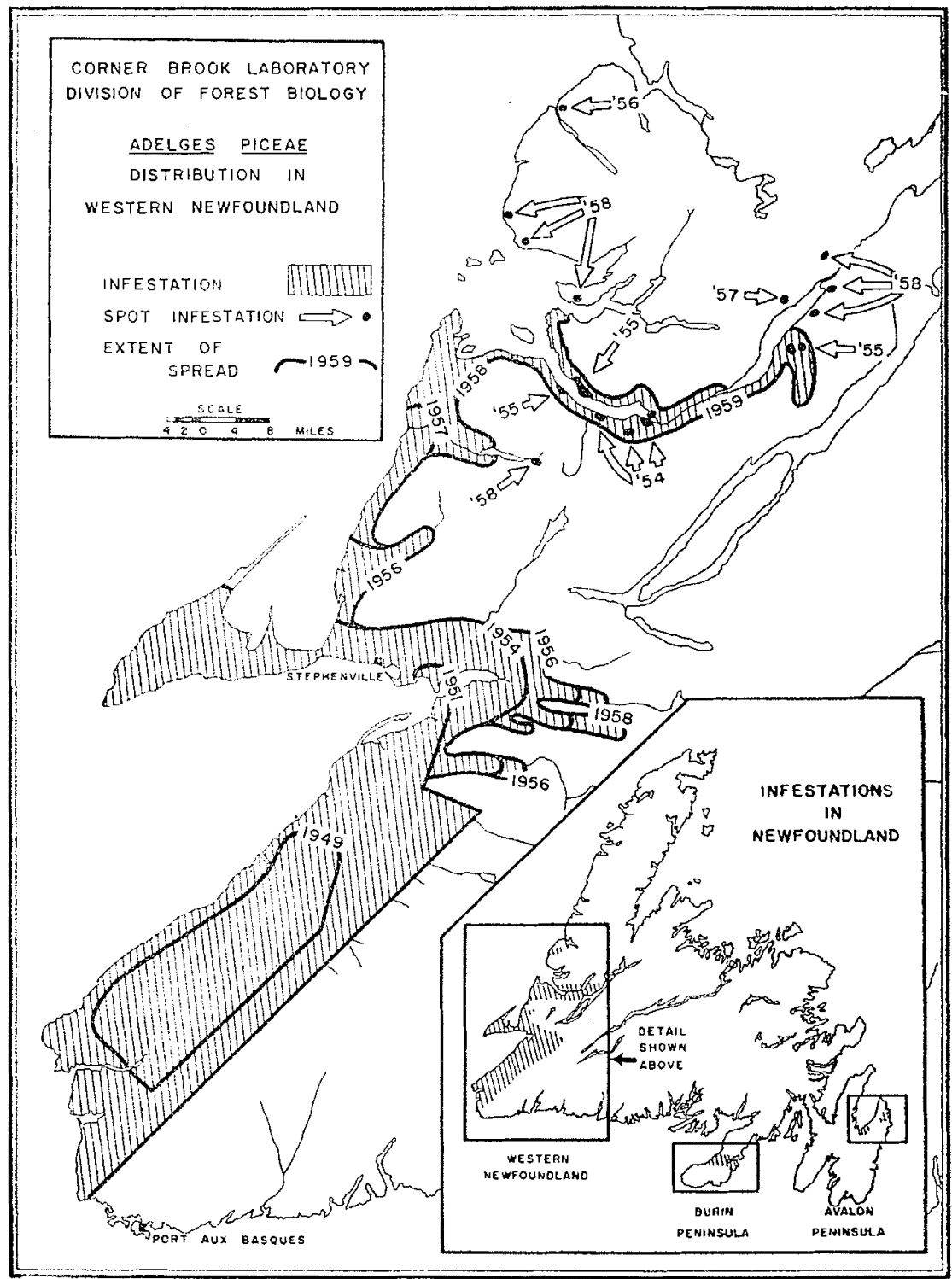

FIGURE 1. Adelges piceae distribution in Western Newfoundland. 
1 and 2 are summaries of data from 1,000 trees in 10 plots; Table 1 compares the changes in 8 plots for the years 1951, 1955 and 1959, and Table 2 shows the annual changes in two plots since 1955.

Mortality of balsam fir has been generally low in all plots except at Cold Brook where the infestation was already severe when the plot was established in 1955. By 1959, all the trees were infested, 68 were severely injured, and 30 were dead. This plot was located on a well-drained site in a lightly stocked stand of mature balsam fir about 55 feet high and averaging 6 inches in diameter.

TABLE 1

Infestation and Mortality by 100-Tree Permanent Sample Plots IN SOUTHWESTERN NEWFOUNDLAND FOR 1951, 1955 AND 1959

\begin{tabular}{|c|c|c|c|c|c|c|c|c|}
\hline \multirow[b]{2}{*}{ Location } & \multirow[b]{2}{*}{ Year } & \multirow[b]{2}{*}{$\begin{array}{l}\text { Unin- } \\
\text { fested }\end{array}$} & \multirow[b]{2}{*}{$\frac{\text { Stem }}{\text { Infested }}$} & \multirow[b]{2}{*}{$\frac{\text { Attack }}{\text { Dead }}$} & \multicolumn{3}{|c|}{ Goat } & \multirow[b]{2}{*}{ Cut } \\
\hline & & & & & Light & $\begin{array}{c}\text { Dying } \\
\text { branches }\end{array}$ & Dead & \\
\hline & & & & $(\mathrm{Nl}$ & ber of & Trees) & & \\
\hline South Branch & $1951^{1}$ & - & 一 & - & - & - & - & - \\
\hline South Branch & 1955 & 19 & - & 一 & 37 & 44 & - & - \\
\hline South Branch & 1959 & 7 & - & - & 33 & 55 & 1 & 4 \\
\hline Cold Brook & $1951^{1}$ & - & - & - & - & - & 一 & 一 \\
\hline Cold Brook & 1955 & 4 & - & - & 15 & 78 & 3 & - \\
\hline Cold Brook & 1959 & - & - & - & 2 & 68 & 30 & - \\
\hline North Branch & $1951^{1}$ & - & - & - & $\ldots$ & - & - & 一 \\
\hline North Branch & 1955 & 99 & 1 & - & 1 & 一 & - & - \\
\hline North Branch & 1959 & 61 & - & 一 & 33 & 6 & - & - \\
\hline Highlands & 1951 & 38 & - & - & 47 & 15 & - & - \\
\hline Highlands & 1955 & 14 & 一 & - & 26 & 60 & - & 一 \\
\hline Highlands & 1959 & - & - & - & 14 & 86 & - & - \\
\hline Crabbes River & 1951 & 10 & - & - & 29 & 61 & - & - \\
\hline Crabbes Rivet & 1955 & 1 & - & - & 14 & 85 & - & - \\
\hline Crabbes River & 1959 & - & - & - & 4 & 96 & - & - \\
\hline Flat Bay & 1951 & 39 & - & - & 33 & 28 & - & - \\
\hline Flat Bay & 1955 & 3 & - & - & 10 & 87 & - & - \\
\hline Flat Bay & 1959 & - & - & - & 9 & 8.3 & 6 & 2 \\
\hline Stephenville & $1951^{1}$ & - & - & - & - & - & - & - \\
\hline Stephenville & 1955 & 96 & 3 & - & 1 & - & - & 一 \\
\hline Stephenville & 1959 & 1 & - & - & 45 & 48 & - & 6 \\
\hline Dhoon Lodge & $1951^{1}$ & - & - & - & - & - & - & - \\
\hline Dhoon Lodge & 1955 & 100 & - & - & - & - & - & - \\
\hline Dhoon Lodge & 1959 & 100 & - & - & - & - & - & - \\
\hline John's Beach & $1951^{1}$ & - & - & - & - & - & - & - \\
\hline John's Beach & 1955 & 45 & 52 & - & 2 & 1 & - & - \\
\hline John's Beach & 1959 & - & 9 & - & 39 & 45 & 3 & 4 \\
\hline Wild Cove & $1951^{1}$ & - & - & - & - & - & - & - \\
\hline Wild Cove & 1955 & 16 & 78 & - & 6 & - & - & - \\
\hline Wild Cove & 1959 & - & - & - & 36 & 59 & 2 & 3 \\
\hline
\end{tabular}

'Not established. 
TABLE 2

INFESTATION SUMMARY OF ANNUAL TALlIES OF TWo 100-TREe Permanent Sample Plots in Southwestern Newfoundland

\begin{tabular}{|c|c|c|c|c|c|c|c|c|c|}
\hline \multirow[b]{2}{*}{ Lacation } & \multirow{2}{*}{ Year } & \multirow{2}{*}{$\begin{array}{l}\text { Unin- } \\
\text { fested }\end{array}$} & \multirow{2}{*}{\multicolumn{3}{|c|}{ Stem attack }} & \multicolumn{3}{|c|}{ Gout } & \multirow[b]{2}{*}{ Cut } \\
\hline & & & & & & Light & $\begin{array}{c}\text { Dying } \\
\text { branches }\end{array}$ & Dead & \\
\hline \multirow{6}{*}{ North Branch } & & & & & (Nul & ber of & Trees) & & \\
\hline & 1955 & 99 & - & - & - & 1 & - & - & - \\
\hline & 1956 & 91 & 4 & - & - & 5 & - & - & - \\
\hline & 1957 & 87 & 一 & - & - & 12 & 1 & - & - \\
\hline & 1958 & 74 & - & - & - & 22 & 4 & - & - \\
\hline & 1959 & 61 & - & - & 一 & 33 & 6 & - & - \\
\hline \multirow[t]{5}{*}{ Stephenville } & 1955 & 96 & 3 & - & - & 1 & 一 & - & -- \\
\hline & 1956 & 20 & 33 & - & - & 40 & 7 & 一 & $\ldots$ \\
\hline & 1957 & 20 & - & - & 一 & 46 & 34 & - & 一 \\
\hline & 1958 & 4 & 10 & 1 & - & 33 & 46 & - & 6 \\
\hline & 1959 & 1 & - & $\ldots$ & - & 45 & 48 & - & 6 \\
\hline
\end{tabular}

The Crabbes River, Highlands, and Flat Bay plots were established in fairly dense, immature balsam stands, about 35 feet high and with a diameter of 5 to 6 inches. In 1951, 90 trees were infested in the Crabbes River plot and 62 and 63 in the Highlands and Flat Bay plots respectively. In 1959, all the trees were affected and 85 per cent of the trees in the three plots showed advanced stages of golt. In the South branch plot, established in a similar stand in 1955, the number of infested trees had increased from 81 to 93 by 1959 and 55 were severely injured.

The two plots summarized in Table 2 were selected for comparison because of the light infestation present when they were established and the marked difference between them in the progress of the attack. The North Branch plot is in an immature balsam fir stand, 40 to 50 feet high, about 15 miles inland; the Stephenville plot is in an immature stand, 25 to 30 feet high, about 2 miles from the coast. The two stands have approximately the same density. Over the four-year period the number of gouty trees has increased by 38 in the former plot and by 95 in the latter. The difference demonstrated by these plots is indicative of the more rapid progress of infestations in coastal regions.

Twig attack predominates in the older infestations and stem attack was recorded on only three trees of 700 tallied in plots south of Stephenville where the outbreak has been established for 10 or more years. In the more recent infestations, of less than five years' duration, e.g., John's Beach and Wild Cove, more than one-half of the trees tallied showed varying intensities of stem attack. These data give additional support to field observations that stem infestations are more prevalent in the newer outbreaks which generally develop as spots of stem attack followed by generalized twig attack.

General observations have shown that the above data are fairly representative of average conditions and illustrate the destruction caused by the aphid. In 1959,83 per cent of the balsam fir trees tallied showed varying symptoms of injury and over 50 per cent were severely injured. Included in this tally is the plot at Dhoon Lodge which, although within the area of distribution of the 
aphid, is uninfested. This plot indicates the extreme irregularity of infestations, which makes it difficult to estimate the total loss involved. However, the balsam woolly aphid is causing more damage to pulpwood stands in southwestern Newfoundland than any other forest enemy.

Extensive surveys have failed to show any consistent relationship between forest composition or site quality and the amount of damage. An unpublished report by van Nostrand (12) shows that in mature stands susceptibility increases with stand density, and in immature stands the converse is true. Balch (1) has observed that lightly stocked stands with deep-crowned trees show more damage than fully stocked stands and this is also supported by observations in Newfoundland. An analysis of data from permanent cruise lines of the Forest Insect Survey shows that in certain predominantly spruce stands the proportion of gouty balsam fir ranges from 80 to 100 per cent, while in other similar stands there was only slight damage. Similar inconsistencies indicate no relationship between site quality and susceptibility. Severe injury has been recorded on relatively well-drained deep soils as well as on poorly-drained thin soils. Present knowledge is too incomplete to permit generalization on the relationship between stand and site characteristics and damage, and more detailed studies are needed of such factors as location, exposure, composition, density, and age of stands.

\section{Introduced Predators}

\section{Control}

When insects are accidently introduced into a new country, they frequently become extremely numerous and cause more severe damage than in the country of origin. It is sometimes possible to improve the natural control of such pests by also introducing its parasites, predators or diseases. No parasites or diseases of the balsam woolly aphid are known but several species of insect predators do attack it and related species in Europe and other parts of the world. An important problem confronting the application of this biological control measure in Newfoundland is the prevalence of twig attack, and predators that are effective against stem population are less valuable against this form of attack.

A biological control program was initiated in Newfoundland in 1952 and seven species of predators have been introduced (Table 3). All releases have been made in southwestern Newfoundland (Figure 2) on trees with moderate to severe stem attack. Three species have become established. The most striking example of rapid establishment and dispersal is provided by a predacious fly, Neoleucopis obscura (Hal.). In 1959, three years after introduction, it was recovered up to 22 miles from the release point. It has outnumbered and appears to have replaced a native predator, Leucopis americana Mall. In 1956, population levels of the latter species were fairly high and several hundred puparia and larvae were collected. In 1959, $298 \mathrm{~N}$. obscura were collected but only one L. americana. Balch, Clark and Brown (2) report that $N$. obscura is dependent on a high prey density and has been found only on heavily infested stems in New Brunswick. Its main feeding stages occur too late to prevent hatching of a large proportion of aphid eggs and, although it has apparently ehecked the rate of injury and spread, the killing of trees has continued. In 


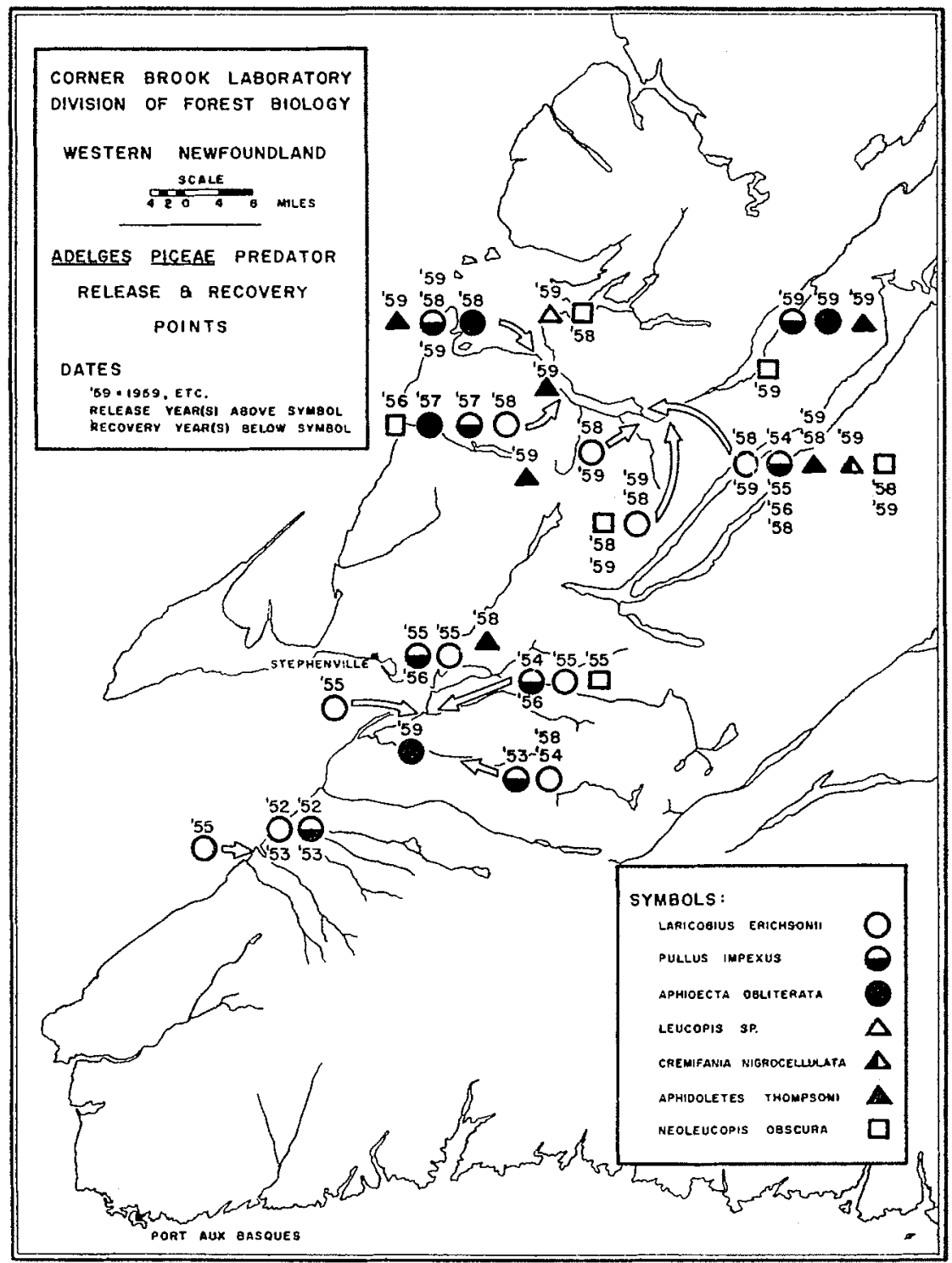

FIGURE 2. Adelges piceae predator release and recovery points. 
TABLE 3

Annual Releases of Seven Species of European Insect Predators Against the Balsam Woolly Aphid in Newfoundland

\begin{tabular}{|c|c|c|c|c|c|c|c|c|}
\hline Species & 1952 & 1953 & 1954 & 1955 & 1956 & 1957 & 1958 & 1959 \\
\hline Laricobius & & & & Number & Insect & & & \\
\hline erichsonii Rosen. & 843 & - & 2,502 & 5,424 & - & — & 8,192 & 3,202 \\
\hline $\begin{array}{l}\text { Pullus impexus (Muls.) } \\
\text { Aphidecta }\end{array}$ & 1,306 & 1,534 & 4,570 & 890 & - & 464 & 513 & 9,500 \\
\hline $\begin{array}{l}\text { obliterata (L.) } \\
\text { Neoleucopis }\end{array}$ & - & 一 & - & - & - & 16 & 20 & 735 \\
\hline obscura (Hal.) & - & - & - & 21 & 342 & - & - & - \\
\hline $\begin{array}{l}\text { Leucopis sp. } \\
\text { Cremifania }\end{array}$ & - & - & 一 & - & - & - & - & 160 \\
\hline $\begin{array}{l}\text { nigrocellulata } \mathrm{Cz} . \\
\text { Aphidoletes }\end{array}$ & - & - & - & - & - & - & - & 198 \\
\hline thompsoni Möhn. & - & - & - & - & - & - & 120 & 28,935 \\
\hline
\end{tabular}

Newfoundland puparia have been found in high numbers on the stems and in low numbers on the branches, in flower cups and under bud scales, on fairly heavily infested twigs. Its control value is uncertain.

Laricobius erichsonii Rosen., a beetle, has been recovered only in small numbers in contrast to New Brunswick where it has become well established and has shown the ability to reduce stem attacks before trees are killed. Its development is well synchronized with the spring generation of the aphid, but it has only one generation a year and has not spread very rapidly. Although first introduced in 1952, it has not spread more than 2,000 feet from any release site in Newfoundland.

Pullus impexus (Muls.) has survived six years but has not dispersed more than a few hundred feet, and the numbers recovered have been low. A somewhat similar situation is reported in New Brunswick and Clark and Brown (5) attribute its lack of success to an inability to withstand temperatures below $5^{\circ} \mathrm{F}$. The insect overwinters as eggs on the bark and the few survivors are possibly those that overwinter beneath the snow-level.

No recoveries have been made of Aphidoletes thompsoni Möhn. and Aphidecta obliterata (L.). Leucopis sp. and Cremifania nigrocellulata $\mathrm{Cz}$. were released for the first time in 1959. Large numbers of larvae and puparia of the latter species were observed two weeks after the release. This species has spread extensively in New Brunswick, but has not become numerous. A small colony of Aphidoletes thompsoni Möhn. was released in 1958 and approximately 29,000 in 1959 . This is a small fly which requires a relatively small amount of food to complete its development and should be capable of establishing itself on lighter infestations, but its control value is not yet known.

Although the introduced predators have helped to reduce the intensity of stem attacks in New Brunswick, they are limited in their capacity to attack lighter infestations. Species capable of maintaining themselves on low populations, particularly on the branches and twigs, are being sought with a view to preventing gout. 


\section{Native Predators}

Native predators have been collected but, except for L. americana prior to 1956, numbers have not been high. Tetraphleps americana Pars. (Hemiptera: Anthocoridae) has been found on stems and twigs of balsam fir in low numbers feeding on all stages of the aphid except the dormant neosistentes. This species appears to have a wide host range and has been collected from white spruce, Picea glauca (Moench) Voss, Scots pine, Pinus sylvestris L., and apple, Malus sp. A brown lacewing, Hemerobius stigmaterus Fitch, and two undetermined mite species have been observed feeding on aphids. At the present time, predators, native and introduced, are not capable of reducing aphid numbers below the level where injury occurs.

\section{Silvicultural Control}

The pattern of aphid attack whereby an outbreak develops from spot infestations that enlarge and coalesce suggests the use of a combined control and salvage operation in these early stages. This approach was taken by Bowater's Newfoundland Pulp and Paper Company at three locations near Corner Brook. In 1955, a small infested area at Three-Mile Dam was clear cut, the merchantable timber was salvaged and the slash and small trees were burnt. The measure was apparently effective as only light twig attack, confined to a few trees, has developed since, in contrast to severe injury that has occurred in somewhat similar unchecked areas. At the other two locations only the merchantable timber was removed and results have been less encouraging. All adjoining stands have become infested. These latter operations were probably started at too late a stage in the outbreak when the aphid was distributed over a wider area than was apparent. This suggests that the timing of a cutting operation for control is extremely important and must be undertaken during the initial stages of the outbreak. It also demonstrates the need for careful annual surveys in uninfested, susceptible regions.

Measures have been instituted by the Provincial Government and by industry to increase the spruce content of stands. Cutting permits issued for Crown Lands within the infested area have no diameter limit for balsam fir, while spruce is either excluded from cutting or a D.B.H. limit of 5 inches is applied. Residents have been requested to restrict their use of a softwood species for fuel to balsam, and cutters are encouraged to leave white spruce trees 4 inches D.B.H. and under.

A proposal to use prescribed burning to increase the spruce content of stands has been made by Frost (6) who has designated areas in southwestern Newfoundland where safe burning would be possible. Van Nostrand (12) stated that, if burning were undertaken, 50 to 60 per cent of the infested stands south of Stephenville Crossing would regenerate naturally to black spruce. Frost's proposal has not received full support because of the fire hazard involved and the anticipated high cost of such an experimental project. Many stands of high spruce content in eastern Newfoundland were produced by fire, indicating the potential value of fire as a means of reducing the balsam fir content of forest stands.

\section{Climatic Control}

Balch (1) has concluded that low winter temperatures are of prime im- 
portance in limiting distribution and numbers of the balsam woolly aphid. He has suggested that the lethal minimum is in the neighbourhood of $-30^{\circ} \mathrm{F}$., although length of exposure, air movement, and humidity are probably important. Insects beneath the snowline are generally protected. The amount of protection afforded by bud and bark scales under which some aphids overwinter is unknown. Low temperatures around $-30^{\circ} \mathrm{F}$. are rare in Newfoundland although in January, 1957 , minimums of $-29^{\circ} \mathrm{F} .,-32^{\circ} \mathrm{F}$. and $-39^{\circ} \mathrm{F}$. were recorded in western Newfoundland. Aphid mortality was reflected in increased shoot growth of infested trees, but small swellings on these shoots indicate the presence of small numbers of aphids, suggesting only temporary recovery. The rate of development of outbreaks was also reduced in 1957 as indicated in Table 2 where only a four per cent increase in the proportion of infested trees occurred in one plot and no change in the other, in contrast to an average increase of 20 per cent in other years. Evidently, low temperatures reduce numbers periodically but not sufficiently to prevent outbreaks.

The shorter period for seasonal development at higher altitudes and latitudes may prevent completion of the second generation. The period of persistent thaw which approximates the seasonal activity of the aphid is from two to three weeks shorter above the 1,000-foot elevation, and above $50^{\circ}$ North latitude, than in the valleys of southwestern Newfoundland. This will not prevent outbreaks but may limit their development. Infested trees have been found in Newfoundland at elevations up to 1,000 feet, although damage decreases rapidly with altitude above 700 feet. Balch (3) reported severe damage at the 1,500-foot level on Cape Breton Island. Outbreaks may, therefore, develop at higher elevations in Newfoundland, and in northern regions, wherever the host tree is present.

\section{Future Status of Outbreaks}

The natural spread of the insect will be influenced by various factors including clear cutting of spot infestations. Outbreaks will undoubtedly extend to the remaining areas of southwestern Newfoundland, including the Grand Lake Basin. The aphid can survive on the Northern Peninsula, but the progress of outbreaks is likely to be slower than in the Codroy and Humber valleys. At present, the river valleys in the Stephenville area are the most likely sources through which the infestation could extend into central Newfoundland. Severe damage already occurs in these valleys to within 15 miles of Lloyds Valley from where, if once established, the insect could spread throughout the central region. The 10 to 12 miles of moss barren, which separates the two areas, may delay the progression of outbreaks, but motile larvae transported by the prevailing southwesterly winds could eventually cross this barrier. Another possible entry into central Newfoundland is from the northern coastal regions should the present infested area continue to extend. Dispersal inland would be relatively slow against the prevailing winds, and the higher spruce content of the coastal forests would limit the numbers of motile larvae.

Any extensive spread of the Avalon Peninsula outbreak appears unlikely because of the barrens on its western boundary. The Burin Peninsula outbreak is also isolated by barrens on its northern boundary. However, the valleys of the South Coast are quite vulnerable to infestation from this source and provide access to the forests of central Newfoundland. 


\section{ACKNOWLEDGEMENTS}

The authors wish to thank Dr. R. E. Balch and Dr. B. M. McGugan for their criticism of the manuscript, and the Forest Biology Rangers for compiling permanent sample plot data.

\section{REFERENCES}

1. BALCH, R. E. 1952. Studies of the balsam woolly aphid, Adelges piceae (Ratz.), and its effects on balsam fir, Abies balsamea (L.) Mill. Pub. 867, Can. Dept. Agr.

2. BALCH, R. E., CLARK, R. C. and N. R. BROWN, 1958. Adelges piceae (Ratz.) in Canada with reference to biological control. Proc. X Int. Congr. Ent. (1956) 4: 807-817. 3. BALCH, R. E. 1956. Damage caused by balsam woolly aphid. Can. Dept. Agr. For. Biol. Div. Bi-mon. Prog. Rept., 12 (5).

4. Bowater's Newfoundland Pulp and Paper Mills, 1955. Results of grinding "woolly aphid" infected wood. Special Report 1007 R. M. Unpublished. April, 1955.

5. CLARK, R. C., and N. R. BROWN, 1959. Predator introductions for balsan woolly aphid control. Can. Dept. Agr., For. Biol. Div. Bi-mon. Prog. Rept., 15 (6).

6. FROST, F. 1957. The balsam woolly aphid and controlled burning of forest land. Mimeographed report, Nfld. Dept. Mines and Resources. Unpublished. Jan. 1956.

7. KOTINSKY, J. 1916. The European fir trunk louse, Chermes (Dreyfusia) piceae (Ratz.). Proc. Ent. Soc., Wash. 18: 14-16.

8. LOUGHLIN, C. C. 1945. Monthly report of forest insect survey to Newfoundland Forest Protection Association. Unpublished.

9. NICKERSON, D. E. 1955. Personal communication.

10. REEKS, W. A., et al. 1949. Forest insects of Newfoundland in 1949. Annual Report of Nfld. Forest Protection Association. 1949. Grand Falls, Nfld.

11. SWAINE, J. M. 1930. Notes on forest insect conditions in Nova Scotia in 1929. Nova Scotia Dept. Lands and Forests Rpt. 1929: 42-46, 1930.

12. VAN NOSTRAND, R. S. 1957. Conversion of balsam fir stands infected by woolly aphid to more resistant species. Can. Dept. of Northern Affairs and Natl. Res., Forestry Branch. Unpublished interim report on 1956 field work. 